\title{
Clay coating preserving high porosities in deeply buried intervals of the Stø Formation
}

\author{
Henrik Nygaard Hansen ${ }^{\mathrm{a},{ }^{*},}$, Kristoffer Løvstad ${ }^{\mathrm{a}}$, Reidar Müller ${ }^{\mathrm{a}}$ and Jens Jahren ${ }^{\mathrm{a}}$ \\ aUniversity of Oslo, Department of Geosciences, Sem Sælands vei 1, 0371 Oslo \\ *Corresponding author: henriknh@mail.uio.no
}

\begin{abstract}
The Stø Formation is the most important reservoir interval in the Norwegian Barents Sea, however the reservoir quality can be highly affected by the detrimental effects of quartz cement where there have been extensive post depositional burial. Core plug data from well 7219/8-2 in the Southwestern Barents Sea shows abnormally high porosity and permeability values in certain units of the deeply buried and otherwise highly quartz cemented Stø Formation. The amount of quartz cement in the samples is inversely proportional to the porosity. Samples with high and low porosities are similar texturally and mineralogically, but the high porosity samples have a layer of illitic clay coating the majority of the detrital quartz grains. Illitic clay coating present at grain contacts can result in a lowered IGV given they aid in the dissolution of quartz at interfaces, also creating a source of dissolved silica. Clay induced dissolution means that silica saturation is not a limiting factor in quartz cementation in these samples. The results show that the illitic clay coating is capable of limiting the amount of authigenic quartz overgrowth from $20-23 \%$ in samples with negligible grain coating to $5-11 \%$ in the intervals with high coating coverage. The illitic clay coating inhibits quartz overgrowth by limiting the surface area available for nucleation on detrital grains. The Stø Formation comprises mainly shallow marine deposits of highly reworked clean sandstone. Abnormally high porosities appear to be linked to settings where sediments of a more proximal location are preserved without extensive reworking. The grain coating clay is illitic and most likely originates from clay infiltration processes prior to final deposition. The difference in extent of clay coating in similar facies can mostly be correlated with varying amount of post depositional reworking. This study suggests that there is a potential for considerable porosity and permeability to be preserved in deeply buried sandstones in the Barents Sea. This study could be important in the future exploration activity of deeply buried structures in the area.
\end{abstract}

Keywords: Stø Formation; Barents Sea; Reservoir quality; Diagenesis; Quartz cementation; Grain coating; Illite; Porosity preservation. 


\section{Introduction}

In this study samples from the Stø Formation in well 7219/8-2 are investigated with respect to porosity preserving processes during deep burial. The Stø formation is present across most of the Norwegian Barents Sea and is an important target for petroleum exploration (Worsley et al., 1988). The formation is mainly composed of clean mature sandstone (Olaussen et al., 1984) that has been subjected to large maximum burial depths in areas (formation depths from wells available at the Norwegian Petroleum Directorate, uplift corrected using data from Baig et al. (2016)), and can thus be subjected to extensive quartz cement growth, causing low porosities. From core plug measurements provided to the authors by Tullow oil (data released 2015), an interval of the Stø Formation in well 7219/8-2 is identified as having porosity values above other intervals of the Stø Formation in the same well with a similar mineralogical composition.

Reduction of porosity in sandstones with increasing burial is a function of mechanical compaction causing reorganization and crushing of grains with increasing pressure, with the sediments' response to increasing pressure being determined by the textural and mineralogical parameters e.g. (Bjørlykke et al., 1989, Lundegard, 1992, Chuhan et al., 2002, Paxton et al., 2002, Marcussen et al., 2010). At temperatures exceeding 70-80 ${ }^{\circ} \mathrm{C}$ rates of authigenic quartz cementation become significant (McBride, 1989, Bjørlykke and Egeberg, 1993). Quartz cementation is commonly considered the main controlling factor of the porosity distribution in deeply buried clean sandstone reservoirs (Bjørlykke and Egeberg, 1993). The amount of quartz cement can be reduced if grain coats cover a large part of the surface of detrital quartz grains (Heald and Larese, 1974). Grain coats hampering the precipitation of quartz cement by reducing the surface area available for nucleation of authigenic quartz on detrital grains have been observed and discussed in several papers from the Norwegian continental shelf, mainly from the North Sea and Norwegian Sea (Ehrenberg, 1993, Aase et al., 1996). Primarily microquartz and authigenic chlorite coating have been found to preserve porosities well above the porosity depth trend in deeply buried sandstones. Storvoll et al. (2002) also found that illite or illite/chlorite coating could reduce quartz cement. Other important factors to consider is stylolitization (Ehrenberg, 1990), clay mineralogy (Walderhaug et al., 2006) and textural properties (Chuhan et al., 2002, Fawad et al., 2011). In the Barents Sea, Walderhaug and Bjørkum (2003) related differences in quartz cement volume to stylolite spacing within the Stø Formation from well 7120/6-1 situated in the Hammerfest Basin. Exceedingly clean sediments can lack sufficient clay to form significant stylolites resulting in a high stylolite spacing $(>20 \mathrm{~cm})$, limiting the supply of silica in solution to the sediments due to the limited ability of the pore fluids to diffuse over large distances $(>20-30 \mathrm{~cm}$ ) (Walderhaug and Bjørkum, 2003). 
The aim of this study was to investigate any higher than expected porosities in deeply buried intervals of the Stø Formation and its causes. The Stø Formation in well 7219/8-2 were well suited for this study since it has had a significant maximum burial depth and also clearly defined intervals of varying porosity with a similar lithological composition.

\section{Geological Setting}

The Barents Sea is an epicontinental platform situated on the Northwestern flank of the Eurasian continental plate. Well 7219/8-2 is located in the Bjørnøyrenna Fault Complex just west of the Polhem sub-platform (Figure 1).

The Stø Formation is a part of the Realgrunnen Subgroup and is late Pliensbachian to Bajocian in age. The original sediments of the Stø Formation is interpreted to have been deposited in a prograding coastal regime interrupted by several transgressive events marked by thin siltstone and shale layers, and generally consists of very mature sandstones that are moderately to well sorted (Olaussen et al., 1984, Gjelberg et al., 1987, Worsley et al., 1988, Klausen et al., in press). The sandstones of the Stø Formation usually have a quartz content of 91 to $100 \%$ (Bergan and Knarud, 1993). The mature sandstones probably reflect extensive reworking owing to the shallow marine/coastal depositional environment (Worsley, 2008), and also partly the mature source area (Bergan and Knarud, 1993, Ryseth, 2014). The Stø Formation was deposited in a low accommodation setting over a period of 14 million years, with several transgressive and regressive events caused by relative sea level change and with three major transgressive events forming a basis for an overall division of the formation into three stratigraphic units (Olaussen et al., 1984, Gjelberg et al., 1987).

The Stø Formation is overlain by the Fuglen Formation, characterized by pyritic mudstones and interbedded limestones (Worsley et al., 1988). Underlying the Stø Formation is the Nordmela Formation characterized by interbedded sandstones, siltstone, mudstone and claystone (Worsley et al., 1988).

The present day depth of the Stø Formation in the well is shown in Table 1. The formation most likely reached maximum burial in the Eocene or Oligocene (Baig et al., 2016). Subsequent uplift of the Barents Sea area means that the present day burial depth does not represent maximum burial.

The amount of uplift varies across the Southwestern Barents Sea, generally increasing towards the North-East, The Bjørnøyrenna Fault Complex and Ringvassøy-Loppa Fault complex are assumed to have experienced an uplift of $\sim 1000 \mathrm{~m}$ (Baig et al., 2016). 


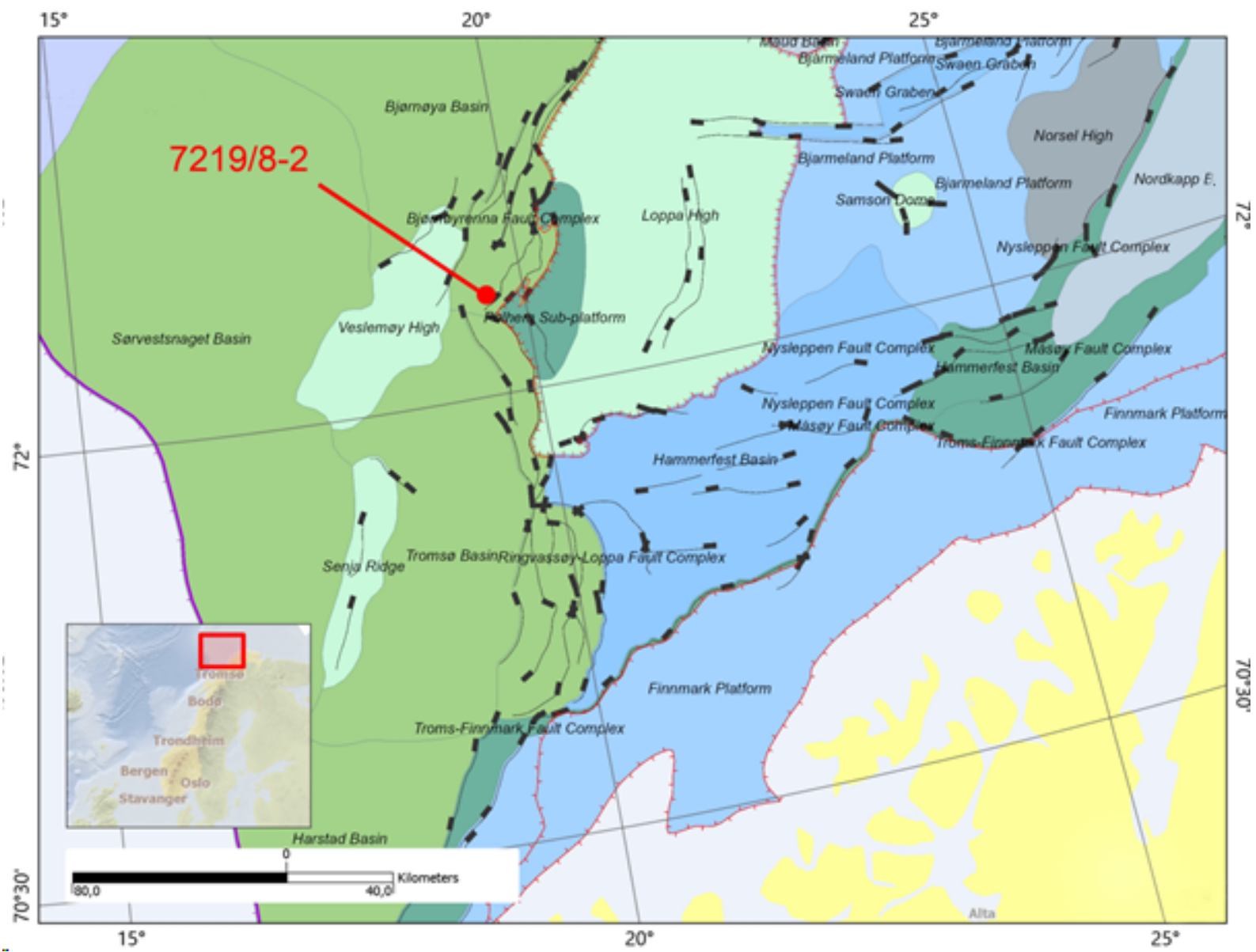

Figure 1: Position of the studied well in the Southwestern Barents Sea on a structural map (Norwegian Petroleum Directorate FactMap, retrieved 14.06.2017 from http://gis.npd.no/factmap)

\section{Methods and data}

Eleven thin sections were prepared from core samples from the Stø Formation in well 7219/8-2 at the Norwegian Petroleum Directorate. The samples were selected based on core plug measurements of porosity and permeability provided to the authors by Tullow Oil. Each thin section was point-counted once with 300 counts per sample and the longest axis was measured for approximately 100 randomly picked grains. Grain size measurements formed the basis for the sorting calculation, where the measurements were converted to phi scale utilizing the Wentworth grain size scale, $\left(\varphi=-\log _{2} d\right)$ and calculated using the method defined by Folk and Ward (1957). All depths mentioned in this study refer to the measured depth in meters below rotary table $(\mathrm{mRKB})$ unless otherwise stated. Nine thin sections were inspected in a Scanning Electron Microscope (SEM) using Backscattered electrons (BSE) in order to detect grain coating and their clay mineralogy. The SEM also has cathode luminescence $(\mathrm{CL})$ which was used to detect authigenic quartz growth. SEM analyses where not conducted on all thin sections, thus the degree of coating could not be estimated for all 
samples. These samples are still displayed in the results since mineralogical- and textural measurements are available. Inherited grain rims are often hard to distinguish by the use of optical microscopy due to the often limited thickness and varying extent and were determined qualitatively in the SEM. The stylolite spacing is based on analysis of core photos and is defined as the distance between the nearest stylolite above or below each sample. Maximum burial- and temperature history estimates are based on an uplift map by Baig et al. (2016). Core logging was performed on a section of well 7219/8-2 (2947-2972 mRKB) covering a high and low porosity interval. The maximum temperature at the top of the Stø Formation was calculated using the present day geothermal gradient.

\section{Results}

\subsection{Petrographic composition and petrophysical data}

Table 1: General well information is summarized in the table below. *Maximum burial are based on (Baig et al., 2016). Temperature estimates are based on current geothermal gradient. All values are calculated at the top of formation.

\begin{tabular}{lc}
\hline Well name & $\mathbf{7 2 1 9 / 8 - 2}$ \\
\hline Location & $72^{\circ} 19^{\prime} 17.55^{\prime \prime} \mathrm{N}$ \\
& $19^{\circ} 35^{\prime} 21.28^{\prime \prime} \mathrm{E}$ \\
Vertical depth [mRKB] & 3413 \\
Bottom hole temperature $\left[{ }^{\circ} \mathbf{C}\right]$ & 122 \\
Geothermal gradient $\left[{ }^{\circ} \mathbf{C}\right]$ & 38,8 \\
Formation [mRKB] & 11 \\
Thin sections & 1100 \\
Estimated uplift $*$ & 3654 \\
Maximum burial depth $[\mathrm{MD}$ from surface] & 141,7 \\
Maximum burial temperature $\left[{ }^{\circ} \mathbf{C}\right]$ & 99,0 \\
\hline Present day temperature $\left[{ }^{\circ} \mathbf{C}\right]$ & St $\mathrm{Fm})$. \\
\hline
\end{tabular}


The Stø Formation can be classified as a quartz arenite in all the samples as the quartz grain content compared to feldspar grains and rock fragments are close to $100 \%$ (Table 2). The muscovite content do not exeed $1 \%$ in any of the samples, but were sporadically observed to penetrate detrital quartz grains showing clearly the potential of mica to facilitate quartz dissolution at the interfaces of quartz-mica grains (Bjørkum, 1996). Quartz cement is by far the dominant authigenic mineral and varies from about $5-23 \%$ in the studied samples. The primary porosity is also highly variable and ranging from $3-17 \%$. Secondary porosity is negligible in all samples. The pore filling clay content is approximately $1-5 \%$ in the studied samples and the clay consists mainly of illite, but small crushed fragments of quartz- and muscovite grains are commonly incorporated in the clay mixture. In addition, small amounts of pyrite, apatite and ankerite occur in association with the pore filling clay. Pore-filling aggregates of kaolinite is present in nearly all the samples, but commonly makes up less than $1 \%$. Illite was also observed as grain coating in 6 of the studied samples. The illite was partly to completely covering the majority of the detrital quartz grains in these samples. Contacts between coated detrital quartz grains typically are sutured suggesting that dissolution has occurred.

Core plug porosity data from the deeply buried Stø Formation in well 7219/8-2 shows significant higher porosity- and permeability values within certain intervals compared to the overall trend (Figure 2A). A consistently high porosity interval is observed between 2957 $2963 \mathrm{mRKB}$. The porosity distribution, displayed in Figure 2B, has a subpopulation of markedly higher porosities. Based on an uplift estimation by Baig et al. (2016), the maximum burial temperature at the top of the Stø Formation was approximately $141.7^{\circ} \mathrm{C}$ (Table 1 ), assuming a geothermal gradient similar to today. The present day formation temperature is approximately $99^{\circ} \mathrm{C}$ leaving it within the temperature range where quartz cementation can still take place. 

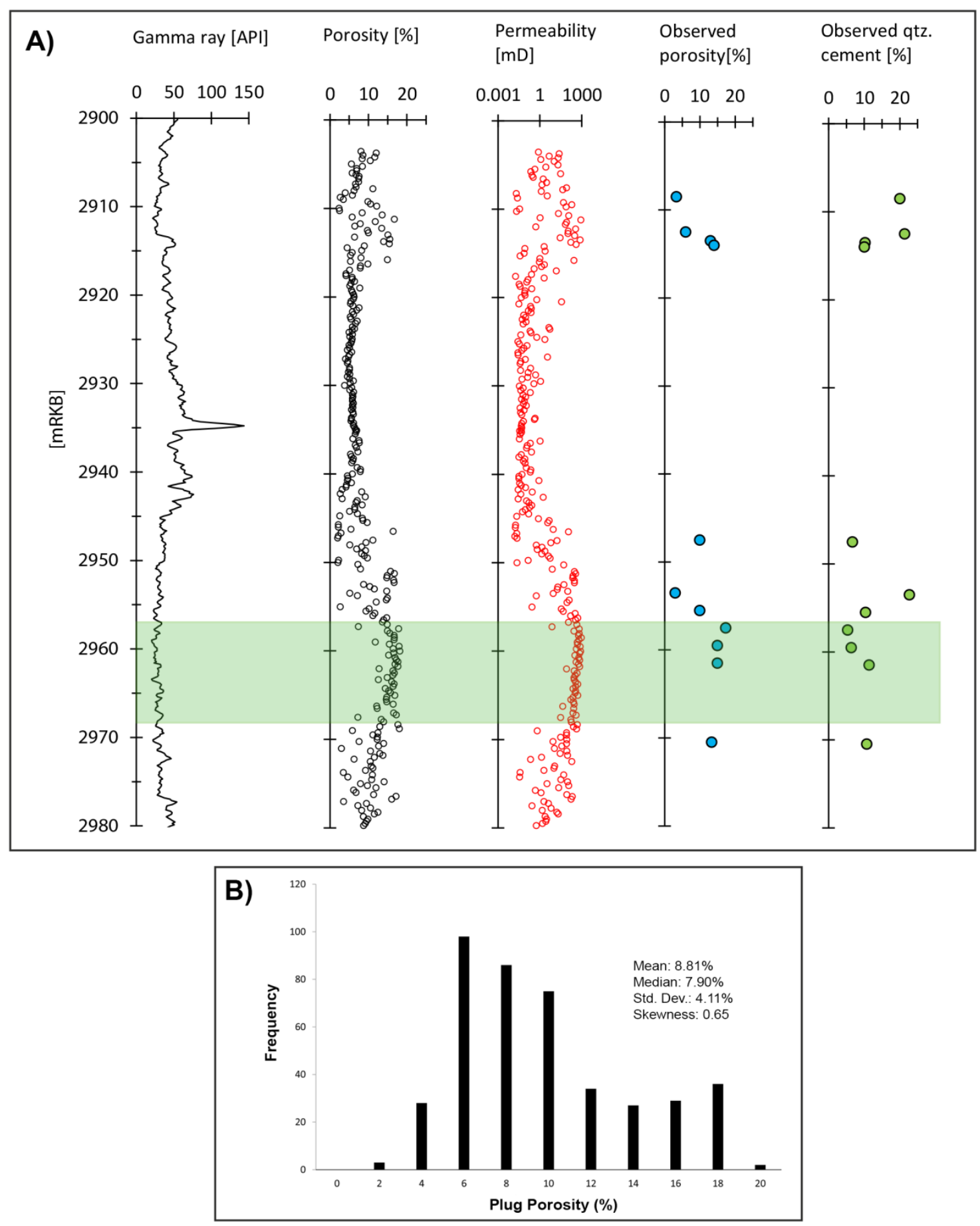

Figure 2: A) Gamma ray log, core plug measurements, and observed porosity and quartz cement volume from the Stø Formation in well 7219/8-2. Core plug porosity (black points), core plug permeability (red points), observed porosity (blue points), observed quartz cement (green points). Observed porosity and quartz cement volume data are obtained from point counting in the optical microscope (Table 2). B) Core plug porosity distribution from the Stø Formation in well 7219/8-2 showing a subpopulation of abnormally high porosities. 
Table 2: Point count results from all studied thin sections. Also marked are which samples that were analyzed in SEM. Samples with coated grains = green, samples with negligible coating $=$ red, undefined samples $=$ white.

\begin{tabular}{|c|c|c|c|c|c|c|c|c|c|c|c|c|c|c|c|}
\hline \multicolumn{10}{|c|}{ Point count results } & \multicolumn{6}{|c|}{ Additional data } \\
\hline Sample & $\begin{array}{c}\text { Quartz } \\
\text { grains } \\
{[\%]}\end{array}$ & $\begin{array}{c}\text { Feldspar } \\
\text { grains } \\
{[\%]}\end{array}$ & $\begin{array}{c}\text { Rock } \\
\text { fragments } \\
{[\%]}\end{array}$ & $\begin{array}{c}\text { Muscovite } \\
{[\%]}\end{array}$ & Clay [\%] & $\begin{array}{c}\text { Quartz } \\
\text { cement } \\
{[\%]}\end{array}$ & Kaolinite [\%] & $\begin{array}{l}\text { Carbonate } \\
\text { cement [\%] }\end{array}$ & $\begin{array}{c}\text { Observed } \\
\text { porosity [\%] }\end{array}$ & $\begin{array}{c}\text { Mean grain } \\
\text { size }[\mathrm{mm}]\end{array}$ & $\begin{array}{c}\text { Sorting } \\
\text { [phi] }\end{array}$ & $\begin{array}{c}\text { Core plug } \\
\text { porosity } \\
{[\%]}\end{array}$ & IGV [\%] & $\begin{array}{c}\text { Stylolite } \\
\text { spacing } \\
{[\mathrm{cm}]}\end{array}$ & SEM \\
\hline 2908,50 & 69,0 & - & 0,7 & 0,3 & 3,7 & 20,0 & 0,7 & 2,3 & 3,3 & 0,17 & 0,47 & 5,9 & 27,0 & 10 & $\checkmark$ \\
\hline 2912,50 & 68,3 & - & - & - & 2,6 & 21,3 & 1,0 & 0,6 & 6,0 & 0,19 & 0,35 & 9,8 & 29,9 & 5 & $\checkmark$ \\
\hline 2913,50 & 75,5 & - & - & - & 1,0 & 10,3 & 0,3 & - & 13,0 & 0,24 & 0,41 & 15,6 & 24,3 & 10 & $\checkmark$ \\
\hline 2914,00 & 71,0 & - & 0,3 & - & 3,0 & 10,0 & 0,3 & 1,3 & 14,0 & 0,29 & 0,52 & 15,5 & 27,0 & 22 & $\checkmark$ \\
\hline 2947,50 & 71,0 & - & 0,3 & 0,3 & 1,7 & 6,7 & 1,3 & 8,7 & 10,0 & 0,15 & 0,38 & 11,2 & 18,3 & 20 & - \\
\hline 2953,50 & 64,0 & - & 0,3 & 1,0 & 4,7 & 22,7 & 1,0 & 3,3 & 3,0 & 0,16 & 0,36 & 5,2 & 30,3 & 12 & $\checkmark$ \\
\hline 2955,50 & 70,3 & - & - & 0,3 & 4,0 & 10,3 & 1,7 & 3,3 & 10,0 & 0,22 & 0,68 & 9,4 & 24,3 & 5 & $\checkmark$ \\
\hline 2957,50 & 71,7 & 0,7 & - & - & 2,0 & 5,3 & 1,0 & 2,0 & 17,3 & 0,26 & 0,55 & 17,9 & 24,7 & 120 & $\checkmark$ \\
\hline 2959,50 & 74,7 & 0,7 & 0,7 & - & 1,0 & 6,3 & - & 1,7 & 15,0 & 0,24 & 0,52 & 18,0 & 22,3 & 80 & $\checkmark$ \\
\hline 2961,50 & 70,3 & - & 0,3 & - & 0,7 & 11,3 & 0,3 & 2,0 & 15,0 & 0,21 & 0,42 & 17,0 & 27,0 & 35 & $\checkmark$ \\
\hline 2970,48 & 69,0 & - & - & - & 3,7 & 10,7 & 3,3 & - & 13,3 & 0,20 & 0,33 & 14,0 & 27,7 & 10 & - \\
\hline
\end{tabular}




\subsection{Sedimentological differences between high and low porosity interval}

The Stø Formation is characterized by a condensed interval of stacked sandstone deposited within a shoreface environment (Olaussen et al., 1984). In well 7219/8-2 the Stø Formation is 88 meters thick and consists of repeated successions of shoreface deposits, with certain intervals of tidal deposits in the lower parts of the formation and offshore transition to shelf deposits in the uppermost parts of the formation (Klausen et al., in press)

The alternating sequence of shoreface deposits with varying energy of deposition exists also in the main studied interval (Figure 3).

Transgressive pulses are common in this interval of the Stø Formation (Olaussen et al., 1984, Klausen et al., in press) and the conglomerate observed (Figure 3) can then possibly be caused by one of these events as a transgressive ravinment surface.

The sandstone above the conglomerate has a grain size population that is slightly finer grained and better sorted than the sandstones below (Table 2). In the interval above the conglomerate vertical burrows are common. The mineralogical composition is the same in both intervals. The better sorting and presence of vertical burrows indicate more reworking in the interval above the conglomerate compared to interval below.

Sandstones in well 7219/8-2 at depths of 2969 to $2957.2 \mathrm{~m}$ - the interval with higher porosities and permeability - appear to have been deposited in a lower energy environment given their poorer sorting and higher degree of preservation of grain coats (Figure 4). 

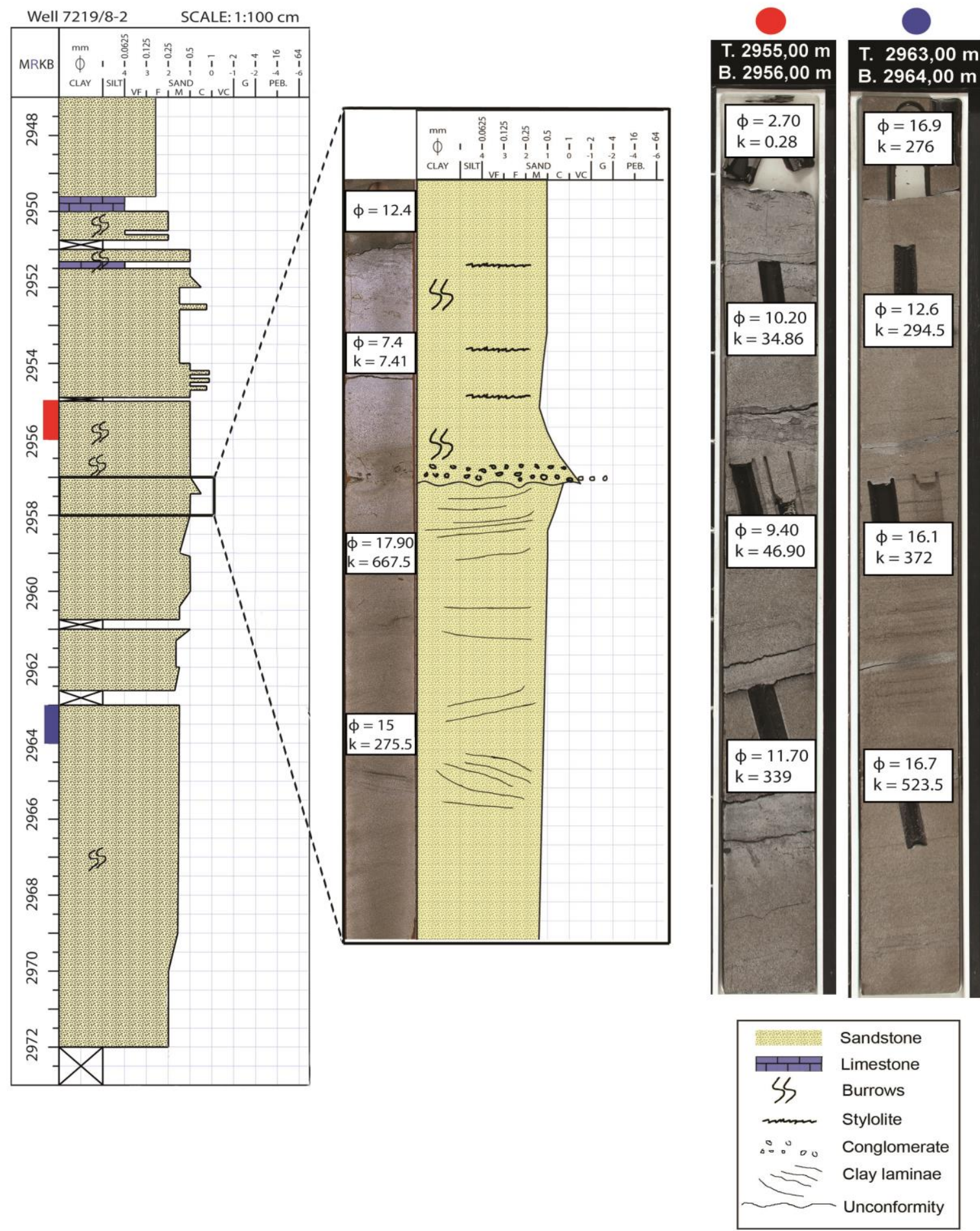

Figure 3: Left: a log covering an interval from 2948 - 2972 m from well 7219/8-2. Center: a more detailed log of the interval $2957-2958 \mathrm{~m}$ and the associated core photo with core plug porosity and permeability values. Note the conglomerate separating the interval with high porosity and permeability below and the interval above with poorer porosity and permeability. Right: two examples of core photos and core plug data above and below the conglomerate. (Red) Core photo from $2955-2956 \mathrm{~m}$, above the conglomerate, showing reduced porosity and permeability. (Blue) core photo of the interval 2963-2964 m showing similar composition and core plug measurements compared to what is observed just below the conglomerate (see Figure 2 for complete core plug database). All depths are given in mRKB. 


\subsection{Properties of grain coating clay}

From core plug data three samples with low porosities (5-11\%) and six samples with high porosities (11-18\%) were selected for SEM analysis (Table 2).

Quartz cement abundances range from 5-10 \% for the high porosity samples and $20-23 \%$ for the lower porosity samples (Table 2). In samples with well-developed grain coating the coating tend to cover the entire grain or be largely absent (Figure $5 \mathrm{C}$ ) these coatings generally have thicknesses in the order of 4 microns where the detrital grain surfaces are smooth but thin to $\sim 1$ micron in places (Figure 5D). Where the detrital grains have significant indentations or rougher surfaces the coating are thicker, up to 20 microns (Figure 4 and Figure 5E). The grain coating clay was chaotic in appearance with the clay particulates often too small to define even in the electron microscope. The outer rim of the grain coating clay generally has an undulating appearance.

As expected the low porosity samples have large, well developed quartz overgrowths on the detrital quartz grains (Figure 5A and B). Only sporadic grain coating clay where observed in these samples with an average of 1 in 20 grains showing traces of coating. Those coatings that are present are generally limited to significant indentations in detrital grains. The areas do not have associated overgrowth cements.

EDS spectra of the grain coating clay show peaks for potassium, aluminum, silica and oxygen but no significant traces of magnesium or iron. The composition and appearance of the clay indicate that the grain coating clay is mainly illitic (Matlack et al., 1989, Dutton and Diggs, 1992). 

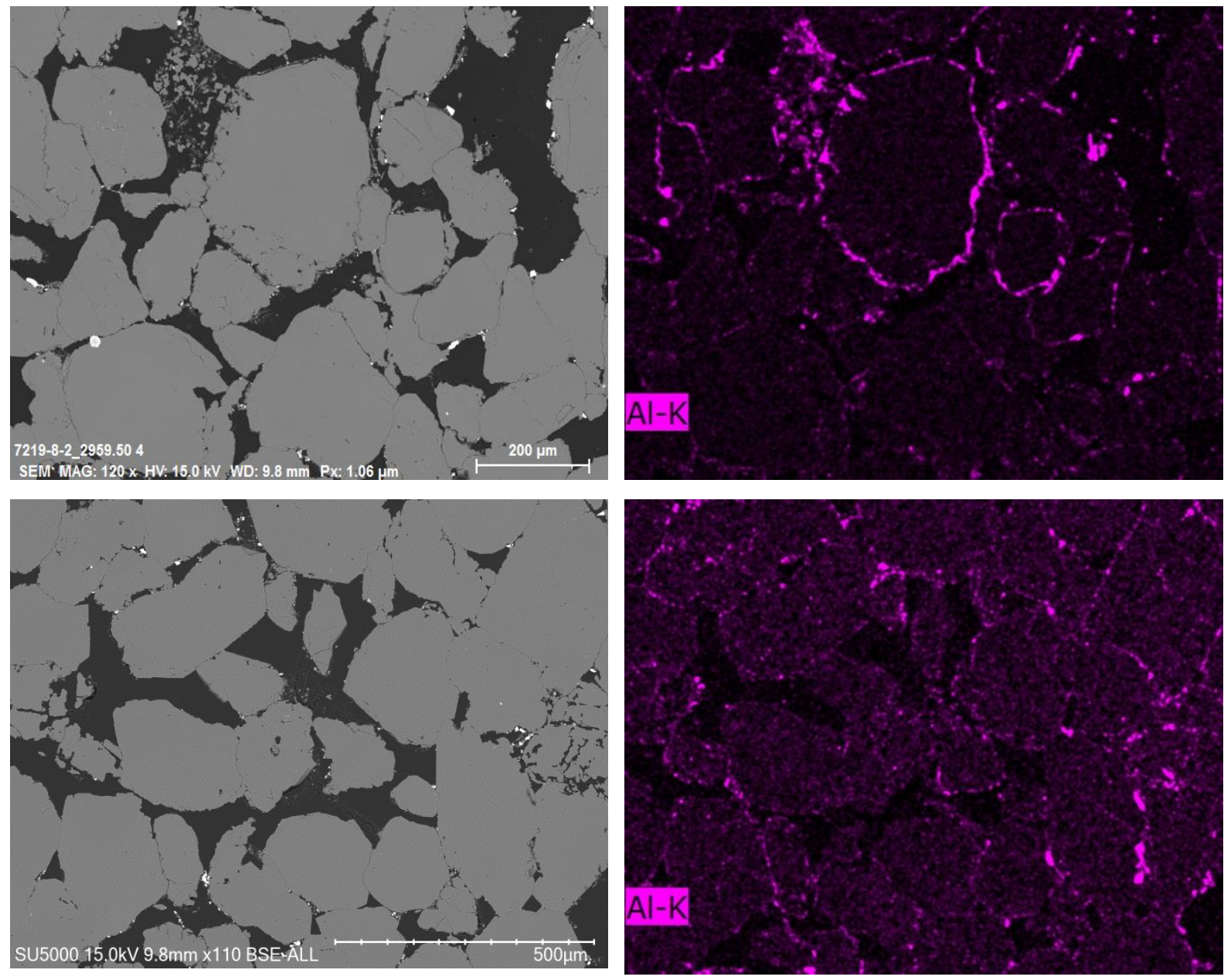

Figure 4: 7219/8-2, $2959.50 \mathrm{~m}$ varying thickness of illitic clay covering the detrital quartz grains. Micrographs on the right show the elemental mapping of aluminum clearly showing the clays surrounding the grains. The elemental mapping on the bottom right image shows more noise as it was acquired over a shorter period of time and with a lower resolution. 

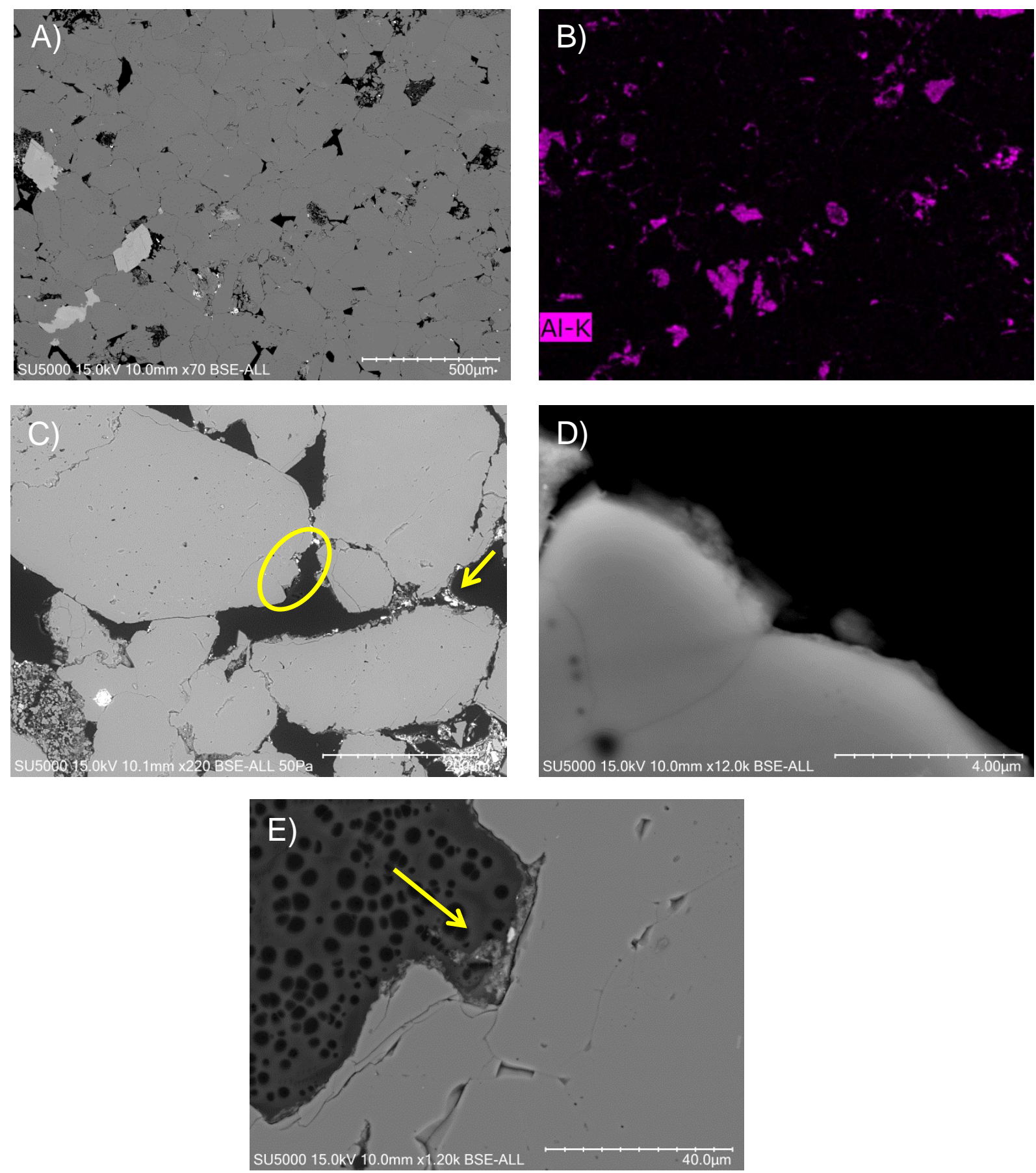

Figure 5: A) $2953.50 \mathrm{~m}$ highly cemented sample with the clay almost exclusively being found in the pore space. B) Elemental mapping of the same area as image A, showing the Al response. C) $2914 \mathrm{~m}$ the coated grains show no signs of authigenic quartz overgrowth. The larger grain on the upper left has significant quartz overgrowth except for the part covered with clay coating (right side of grain). Notice also that there is no clay coat on the authigenic quartz and the pore bridging clays in the right side of the figure. D) $7219 / 8$ $2,2957.50 \mathrm{~m}$ thin layer of illitic clay coating detrital quartz grain. E) $2914 \mathrm{~m}$ the clay can clearly be seen to be thicker in the indentation of the grain. 


\subsection{Diagenetic effects of grain coating}

Samples with well preserved coatings tend to be slightly coarser grained and better sorted compared to samples with negligible grain coating (Figure 6A and Table 2).

The results also show that coated samples have a lower intergranular volume (IGV) and significantly lower amounts of quartz cement (Figure 6B). Sutured grain contacts between quartz grains were commonly observed in samples with significant grain coating (Figure 7) and indicate that dissolution of detrital quartz grains has occurred along the quartz-clay interfaces. This observation is consistent with the lower IGV values observed in coated samples.

The distance to the nearest stylolite above or below each sample was measured, and the results in relation to the observed quartz cement volume can be seen in Figure 6D. The results show that sample 2957.50 and 2959.50 have exceptionally large stylolite spacing and are characterized by a quartz cement volume around $5 \%$. Most of the remaining samples have a stylolite spacing in the range of $10-20 \mathrm{~cm}$, but still a noticeable difference can be observed in the quartz cement volume in these samples. Fractured grains were sporadically recognized in samples examined in the SEM utilizing CL. Comparing the CL- and BSE micrograph obtained from sample $2959.50 \mathrm{~m}$ show that these fractures are partly- to completely filled with quartz cement (Figure 8).

Observed porosity plotted against the observed quartz cement volume demonstrates a correlation between less quartz cement and better preserved porosity (Figure 6C). Samples observed to contain coated grains have a quartz cement volume in the range of $5-11 \%$, whereas samples with uncoated grains have a cement volume between $20-23 \%$. This results in a bimodal distribution of coated and uncoated samples where quartz cement volumes either were below $11 \%$ or above $20 \%$ (marked by black arrow in Figure $6 \mathrm{C}$ ). 
A)

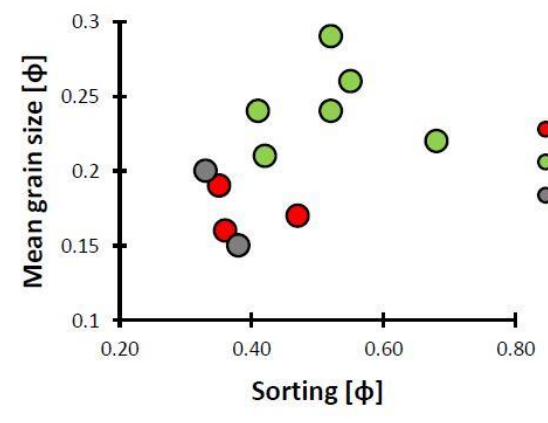

C)

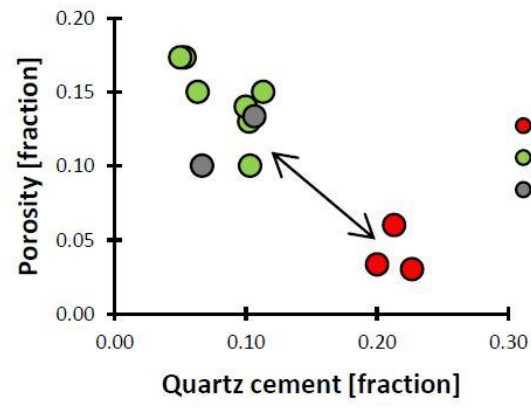

B)

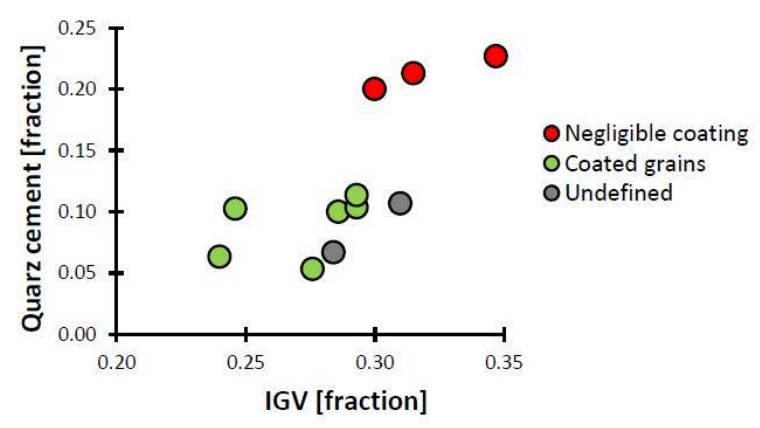

D)

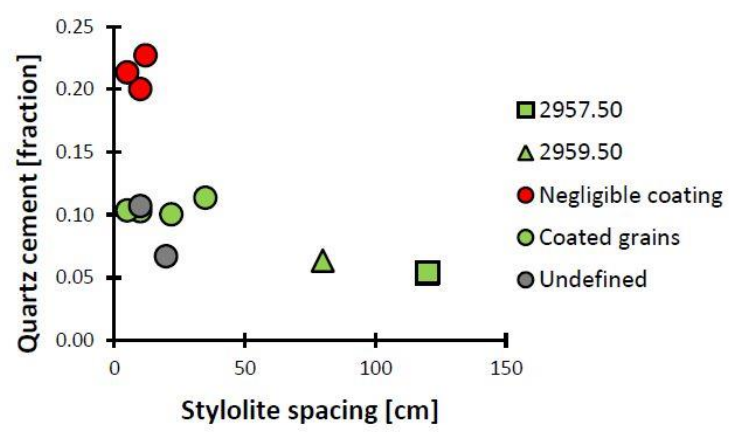

Figure 6: Textural- and diagenetic parameters regarding grain coating and stylolite spacing. Undefined data points represent unexamined samples with respect to the degree of grain coats. A) Sorting and mean grain size (phi scale) categorized with respect to grain coating. B) Displaying the relation between the calculated intergranular volume (IGV), observed quartz cement and grain coating. C) Observed porosity- and quartz cement volume color coded with respect to grain coating. D) The relation between the observed quartz cement volume and the distance to the nearest stylolite above or below each sample. All data from Table 2. 

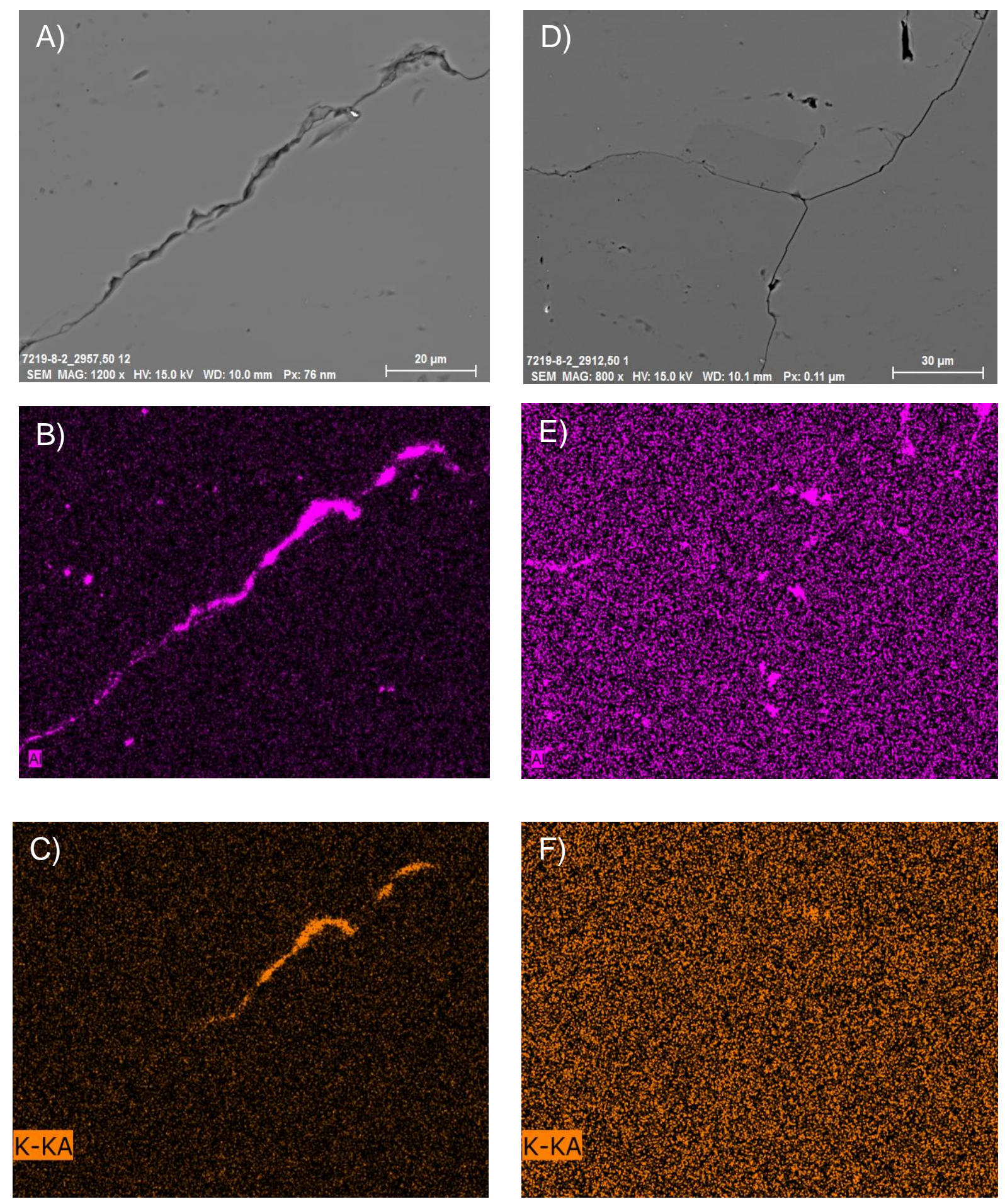

Figure 7: The figure shows two examples of grain contacts: (1) sample $2957.50 \mathrm{~m}(\mathrm{~A}, \mathrm{~B}, \mathrm{C})$ where grain contacts are coated with an illitic clay mixture, (2) sample 2912.50 (D,E,F) where coated grain contacts are negligible. $B, E$ and $C, F$ shows the aluminum- and potassium response, respectively, obtained from elemental mapping in the SEM. 

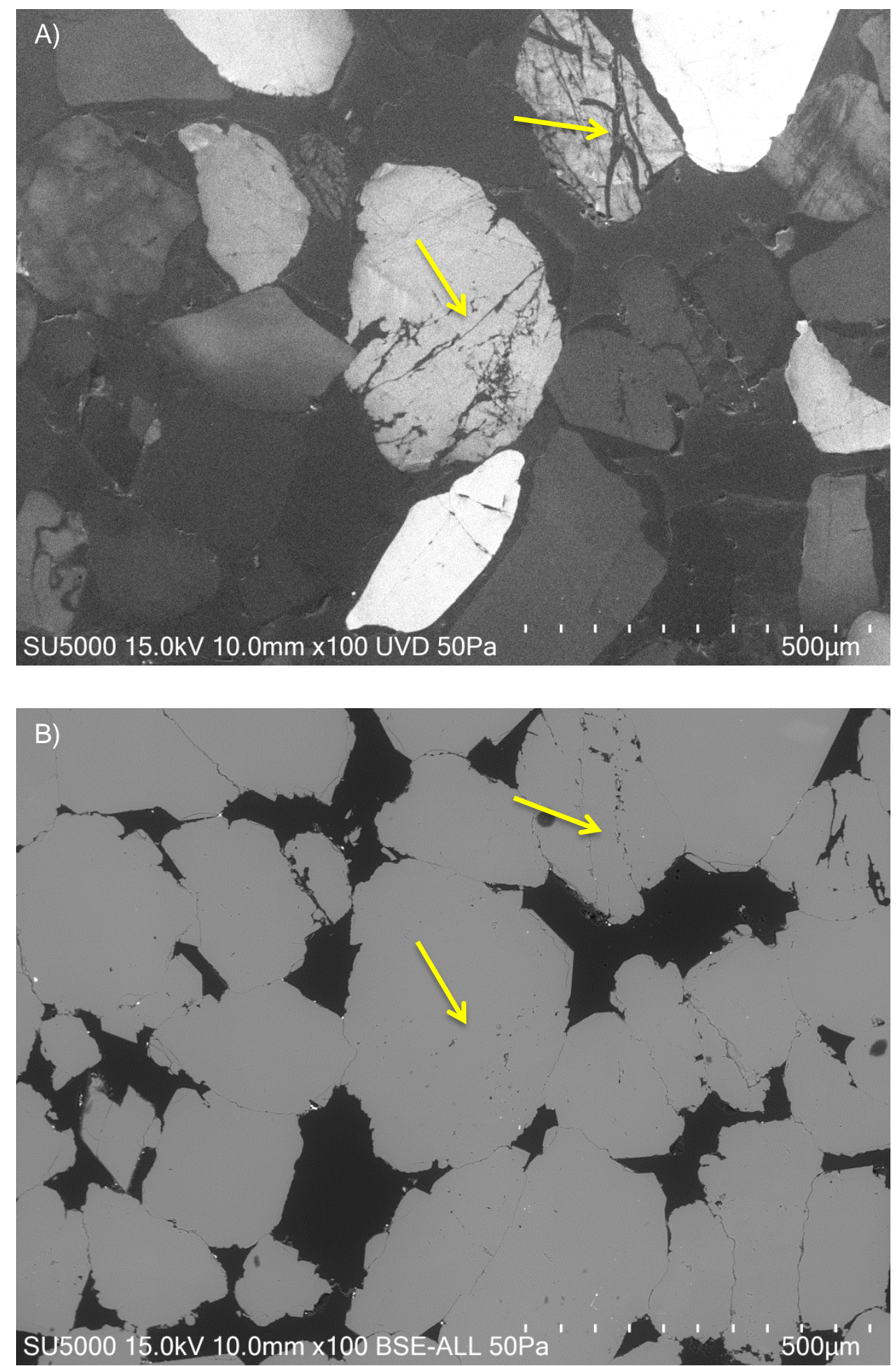

Figure 8: Sample 2959.50 well 7219/8-2. (A) CL-micrograph showing crushed detrital quartz grains from a sample with low quartz cement volume. (B) SEM backscatter micrograph of the same area showing that grain fractures are partly/completely filled with quartz cement. 


\section{Discussion}

\subsection{Intervals with high prevalence of coating in relation to facies}

Within the high porosity intervals of the Stø Formation the majority of grains show at least a partial degree of coating. Coatings are best developed on the rougher grains, with the thickest layer of clay coating observed where there were significant indentations in the detrital grains (Figure 5E). As mentioned in Wilson (1992) infiltration clay will be found in larger extent where the geometry of the detrital grains will allow a more substantial retention of the clay introduced to the sediments. Rough geometry of the grains will aid the preservation of grain coating clay should the sediments be exposed to any subsequent reworking after the emplacement of grain coats. The amount of reworking would therefore have a strong impact on the subsequent reservoir quality of the sediments.

The interface between the clay coats and the pore space were most often undulating and smooth. The amount of coats both in thickness and areal extent were larger on rougher grains. Remnants of grain bridging clay were also observed (Figure 5C). These observations indicate that the grain coats originally formed by means of infiltration processes (Dutton and Diggs, 1992, Wilson, 1992), and were later subjected to a varying degree of reworking. A typical scenario for the clay emplacement would be infiltration by muddy waters on flood plains where the sediments situated in the vadose zone later retained the coating. Infiltrated clays are most easily emplaced in sediments where there exist a high amount of clay in suspension, fluctuating water levels, allowing for intermittent periods of clay retention on grains, and minimal sediment reworking (Matlack et al., 1989). In situ sands in the vadose zone after clay infiltration have both grain coatings and meniscus shaped bridges of clay at grain contacts (Matlack et al., 1989). The grain bridging clays will easily be removed by transport and reworking, but some grain coats would persist in certain units.

The differences between the high porosity interval underlying the conglomerate and the overlying interval with lower porosity (Figure 2) were studied in detail. Both intervals consist of predominantly clean sandstone and the mineralogical composition is the same. The most significant difference between the two intervals is the textural parameters. The sandstone above the unconformity (Figure 3) shows significantly less porosity and permeability and consists on average of marginally finer grains. The sorting is also better than within the underlying interval. The interval above also shows vertical burrows. This difference may be caused mostly by variation in energy of the depositional environment, with the interval above the unconformity being subjected to higher energy and more substantial reworking. 
The unconformity is believed to be caused by a transgressive event, since a pulse of incoming sediments is needed to explain the transition observed. The variation in textural parameters as well as the retention of coating in the sediments below can be explained by an increase in base level, facilitating the preservation of more proximal sediments.

The low relief of the area at time of deposition (Olaussen et al., 1984) means that any eustatic sea level change would impose a significant alteration of the relative location of the coast line. The long period of deposition means that these kinds of events could be quite common in the Stø Formation and would cause a varied distribution of high porosity intervals both laterally and temporally by alternating energy of the depositional setting.

Since traces or remnants of coating where seen also in samples with low porosity it is reasonable to assume that formation of temporarily coated grains was quite common in the Stø Formation. Subsequent variation in degree of clay coating was then determined mostly by the energy of the depositional setting and the preexisting textural and mineralogical properties.

\subsection{Textural and mineralogical properties and diagenetic effects of grain coats}

The IGV (Figure 6B / Table 2) shows a trend where samples with coated grains have a reduced IGV compared to samples where grain coatings are infrequent. The textural properties (grain size/ sorting) of samples with negligible grain coating are not considerably different to samples where grain coats are common (Figure 6A) and are not the cause of the observed difference in IGV. Sutured grain contacts are frequently observed in samples with coated grains indicating that detrital quartz grains are dissolved along grain contacts, due to the presence of the illitic clay coating (Figure 7). Bjørkum (1996) observed interpenetration of detrital quartz grains in samples where a thin layer of illitic clay was present at the point of contact and suggested that dissolution of silica occurred due to a clay induced dissolution process. A lowering of the IGV would be an expected response if quartz grains are dissolved along grain contacts.

Since macro-stylolites are thought to be the main source of dissolved silica (Heald, 1955), the distance to the nearest stylolite above or below each sample is shown in Figure 6D. The results demonstrate that all samples typically have a stylolite spacing of $5-20 \mathrm{~cm}$ and a quartz cement volume between 7-11\%. Sample $2957.50 \mathrm{~m}$ and $2959.50 \mathrm{~m}$ had exceptionally large stylolite spacing $(80-120 \mathrm{~cm})$ and a quartz cement volume of $5,3 \%$ and $6,3 \%$, respectively. Walderhaug and Bjørkum (2003) found that exceedingly clean intervals with 
great stylolite spacing $(>20 \mathrm{~cm}$ ), within the Stø Formation, were characterized by a low quartz cement volume. Based on the SEM BSE- and CL micrograph from sample $2957.50 \mathrm{~m}$ in Figure 8, the sample with a stylolite spacing of $120 \mathrm{~cm}$ and extensive grain coating, fractured quartz grains were observed to be filled with quartz cement. Quartz overgrowths were also commonly detected on grains where the grain coating was discontinuous (Figure $5 \mathrm{C})$. These overgrowth cements indicate that the silica concentration is sufficient for extensive quartz precipitation even within the low quartz cement interval due to the clay induced dissolution process along coated grain contacts, i.e. micro-stylolites. As a consequence, intervals with a low quartz cement volume are believed to be governed by more effective grain coats and not a lack of silica in solution. The effect of high stylolite spacing would probably be more dominant if the illitic clay coating was absent.

Figure $6 \mathrm{C}$ demonstrate the link between high quartz cement volume and poorly preserved grain coating. The difference in quartz cement volume in the most heavily cemented sample $(2953.50 \mathrm{~m})$ and least cemented sample (2957.50) is 17,4\% (Table 2). The intergranular volume in the two samples are 30,3 and $24,7 \%$, respectively, meaning that sample 2953.50 had the highest potential porosity excluding authigenic cements and detrital clay content. The porosity preserving potential in the clay coating is significant and becomes evident where $5,3 \%$ quartz cement and $17,3 \%$ porosity is observed in sample 2957.50 and $22,7 \%$ quartz cement and $3,3 \%$ porosity is observed in sample 2953.50 . In the remaining samples from this study the difference in quartz cement volume between samples with grain coating and samples where grain coating is negligible is in the range of $9-10 \%$ (Table 2). Although this is lower than the difference between the most cemented and the least cemented sample (18\%), 9-10\% less quartz cement will have a critical impact on the porosity. In clean sandstones like the Stø Formation, quartz cement is by far the most important diagenetic process responsible for porosity reduction at burial depths greater than $2-2.5 \mathrm{~km}$.

Thus, the reservoir quality within the Stø Formation in well 7219/8-2 is a function of the effectiveness of the grain coating illite.

The results suggests that deeply buried intervals within the Stø Formation have subpopulations of porosities higher than what would be expected in sandstones with a similar burial history(e.g.(Walderhaug et al., 2001)). A study with a stronger link to sequence stratigraphy should aid in the predictability of high porosity intervals within the Stø Formation. 


\section{Conclusions}

Porosity preserving effects are present in certain intervals of the Stø Formation in the Southwestern Barents Sea. High porosity intervals contain grains coated with illitic clay causing quartz cement volume to be significantly reduced.

- Six samples from intervals comprising coated grains have a quartz cement volume in the range of $5-11 \%$, whereas the three samples where grain coats were observed to be negligible have quartz cement volume of $20-23 \%$.

- The high porosity interval in well 7219/8-2 (2957-2969m) had in general a large stylolite spacing ranging from $35-120 \mathrm{~cm}$. However, there is two strong evidence indicating that the reduced amount of quartz cement do not reflect a lack of dissolved silica but instead reflect decreased area of overgrowth nucleation: (1) Sutured contacts and lower IGV in coated intervals are consistent with a local silica source and (2) Internal fractures within grains are observed to be quartz cemented.

- The appearance and distribution of grain coats indicate they were mainly formed during the final depositional phase for the well coated samples and prior to final deposition in the poorly coated sediments. The variation in the amount of reworking after the main coating phase is therefore controlling the extent and distribution of the coating.

\section{Acknowledgements}

The authors acknowledge financial support from Tullow Oil Norge continued by Pandion Energy. We would like to acknowledge the valuable assistance of Berit L. Berg in the SEM analysis performed for this study. We would like to thank Salahalldin Akhavan for the preparation of the thin sections. We would also like to thank Tore G. Klausen and Robert Lander for their valuable feedback in reviewing this article. Furthermore we would like to thank our friends and colleagues at the department for much appreciated discussions, especially Jørgen A. Hansen. 


\section{References}

Aase, N. E., Bjørkum, P. A. \& Nadeau, P. H. 1996. The role of grain-coating microquartz on preservation of reservoir porosity. AAPG Bulletin, 80(10), 1654-1673

Baig, I., Faleide, J. I., Jahren, J. \& Mondol, N. H. 2016. Cenozoic exhumation on the southwestern Barents Shelf: Estimates and uncertainties constrained from compaction and thermal maturity analyses. Marine and Petroleum Geology, 73, 105130.

Bergan, M. \& Knarud, R. 1993. Apparent changes in clastic mineralogy of the TriassicJurassic succession, Norwegian Barents Sea; possible implications for palaeodrainage and subsidence. Norwegian Petroleum Society conference on Arctic geology and petroleum potential, 2, 481-493.

Bjørkum, P. A. 1996. How important is pressure in causing dissolution of quartz in sandstones? Journal of Sedimentary Research, 66, 147-154.

Bjørlykke, K. \& Egeberg, P. K. 1993. Quartz cementation in sedimentary basins. AAPG Bulletin, 77(9), 1538-1548.

Bjørlykke, K., Ramm, M. \& Saigal, G. 1989. Sandstone diagenesis and porosity modification during basin evolution. Geologische Rundschau, 78, 243-268.

Chuhan, F. A., Kjeldstad, A., Bjørlykke, K. \& Høeg, K. 2002. Porosity loss in sand by grain crushing-experimental evidence and relevance to reservoir quality. Marine and Petroleum Geology, 19, 39-53.

Dutton, S. P. \& Diggs, T. N. 1992. Evolution of porosity and permeability in the Lower Cretaceous Travis Peak Formation, east Texas. AAPG Bulletin, 76(2), 252-269.

Ehrenberg, S. N. 1990. Relationship between diagenesis and reservoir quality in sandstones of the Garn Formation, Haltenbanken, Mid-Norwegian Continental Shelf. AAPG Bulletin, 74(10), 1538-1558.

Ehrenberg, S. N. 1993. Preservation of anomalously high porosity in deeply buried sandstones by grain-coating chlorite: Examples from the Norwegian Continental Shelf. AAPG Bulletin, 77(7), 1260-1286.

Fawad, M., Mondol, N. H., Jahren, J. \& Bjørlykke, K. 2011. Mechanical compaction and ultrasonic velocity of sands with different texture and mineralogical composition. Geophysical Prospecting, 59, 697-720.

Folk, R. L. \& Ward, W. 1957. brazos river bar: a study in the significance of grain size parameters. Journal of Sedimentary Research, 27.

Gjelberg, J., Dreyer, T., Høie, A., Tjelland, T. \& Lilleng, T. 1987. Late Triassic to Mid-Jurassic sandbody development on the Barents and Mid-Norwegian shelf. In: BROOKS, J. \& GLENNIE, K. W. (eds.) Petroleum Geology of North West Europe. Geological Society, London, p. 1105-1129.

Heald, M. T. 1955. Stylolites in Sandstones. The Journal of Geology, 63, 101-114.

Heald, M. T. \& Larese, R. E. 1974. Influence of Coatings on Quartz Cementation. Journal of Sedimentary Petrology, 44(4), 1269-1274.

Klausen, T. G., Müller, R., Slama, J., Olaussen, S., Rismyhr, B. \& Helland-Hansen, W. in press. Depositional history of a condensed shallow marine succession constrainded by U-Pb detrital zircon: The Lower to Middle Jurassic Stø Formation of the Barents Sea. Journal of the Geological Society.

Lundegard, P. D. 1992. Sandstone porosity loss - a "big picture' view of the importance of compaction. Journal of Sedimentary Petrology, 62(2), 250-260.

Marcussen, Ø., Maast, T. E., Mondol, N. H., Jahren, J. \& Bjørlykke, K. 2010. Changes in physical properties of a reservoir sandstone as a function of burial depth - The Etive Formation, northern North Sea. Marine and Petroleum Geology, 27, 1725-1735.

Matlack, K., Houseknecht, D. \& Applin, K. 1989. Emplacement of clay into sand by infiltration. Journal of Sedimentary Petrology, 59, 77-87.

Mcbride, E. F. 1989. Quartz Cement in Sandstones: A Review. Earth-Sciences Reviews, 26, 69-112. 
Olaussen, S., Dalland, A., Gloppen, T. G. \& Johannessen, E. 1984. Depositional environment and diagenesis of Jurassic reservoir sandstones in the eastern part of Troms I area. In: SPENCER, A. M. (ed.) Petroleum Geology of the North European Margin: Proceedings of the North European Margin Symposium (NEMS '83), organized by the Norwegian Petroleum Society and held at the Norwegian Institute of Technology (NTH) in Trondheim 9-11 May, 1983. Dordrecht: Springer Netherlands.

Paxton, S. T., Szabo, J. O. \& Ajdukiewicz, J. M. 2002. Construction of an intergranular volume compaction curve for evaluating and predicting compaction and porosity loss in rigid-grain sandstone reservoirs. AAPG Bulletin, 86(12), 2047-2065.

Ryseth, A. 2014. Sedimentation at the Jurassic-Triassic boundary, south-west Barents Sea: Indication of climate change. In: MARTINIUS, A. W., RAVNÅS, R., HOWELL, J. A., STEEL, R. J. \& WONHAM, J. P. (eds.) From Depositional Systems to Sedimentary Successions on the Norwegian Continental Margins. Chichester, UK.: John Wiley \& Sons, Ltd.

Storvoll, V., Bjørlykke, K., Karlsen, D. \& Saigal, G. 2002. Porosity preservation in reservoir sandstones due to grain-coating illite: a study of the Jurassic Garn Formation from the Kristin and Lavrans fields, offshore Mid-Norway. Marine and Petroleum Geology, 19, 767-781.

Walderhaug, O., Bjorkum, P. A., Nadeau, P. H. \& Langnes, O. 2001. Quantitative modelling of basin subsidence caused by temperature-driven silica dissolution and reprecipitation. Petroleum Geoscience, 7, 107-113.

Walderhaug, O. \& Bjørkum, P. 2003. The effect of stylolite spacing on quartz cementation in the lower Jurassic Stø formation, southern Barents Sea. Journal of Sedimentary Research, 73, 146-156.

Walderhaug, O., Bjørkum, P. A. \& Aase, N. E. 2006. Kaolin-coating of stylolites, effect on quartz cementation and general implications for dissolution at mineral interfaces. Journal of Sedimentary Research, 76(2), 234-243.

Wilson, M. D. 1992. Inherited grain-rimming clays in sandstones from eolian and shelf enviroments: their origin and control on reservoir properties. In: HOUSEKNECHT, D. W. \& PITTMAN, E. D. (eds.) Origin, diagenesis and petrophysics of clay minerals in sandstones, p. 209-225.

Worsley, D. 2008. The post - Caledonian development of Svalbard and the western Barents Sea. Polar Research, 27, 298-317.

Worsley, D., Ofstad, K. \& Kristensen, S. E. 1988. The Mesozoic and Cenozoic succesion of Tromsøflaket. In: DALLAND, A., WORSLEY, D. \& OFSTAD, K. (eds.) $A$ Lithostrategraphic scheme for the Mesozoic and Cenozoic succession offshore midand northern Norway. Norwegian Petroleum Directorate Bulletin 4, 42-65. 